\title{
The Brazilian Swindle and the Larger International Monetary Problem
}

\author{
O embuste brasileiro e o maior problema \\ monetário internacional
}

JAMES K. GALBRAITH*,**

\begin{abstract}
RESUMO: O recente empréstimo do FMI para o Brasil é o mais bem visto como um mecanismo de controle político e não de assistência econômica, exceto em um curto prazo muito insustentável. Assim, escolhas difíceis entre as prioridades da população trabalhadora brasileira e as dos credores internacionais não podem ser evitadas. Este ensaio explora as opções políticas, e continua sugerindo que, embora o setor financeiro esteja certo de dominar a discussão política americana nesses assuntos, seria mais sensato ver o interesse econômico nacional mais amplo dos Estados Unidos alinhado com aqueles que defendem o desenvolvimento nacional sustentável no Brasil.
\end{abstract}

PALAVRAS-CHAVE: Brasil, dívida, FMI; desenvolvimento.

ABSTRACT: The IMF's recent loan to Brazil is the best seen as a mechanism of political control rather than economic assistance, except in a very unsustainable short run. Thus hard choices between the priorities of Brazil's working population and those of international creditors cannot be avoided. This essay explores policy options, and goes on to suggest that while the financial sector is certain to dominate American policy discussion in these matters, it would be wiser to view the larger national economic interest of the United States as aligned with those who advocate stable and sustainable national development in Brazil. KEYWORDS: Brazil; debt; IMF; development.

JEL Classification: F34.

\footnotetext{
* The author is Lloyd M. Bentsen, Jr. Professor of Government/Business Relations at the Lyndon B. Johnson School of Public Affairs, the University of Texas at Austin, Austin/Texas, USA. E-mail: galbraith@operamail.com.

* I wish to thank Dean Baker, Luiz Carlos Bresser-Pereira, Paul Davidson, Tom Ferguson, Wynne Godley, Steve Magee and Robert Wilson for widely divergent but very helpful comments on earlier drafts. Submitted: 6/August/2002; Approved: 17/September/2002.
} 
The International Monetary Fund (IMF) has offered Brazil a $\$ 30$ billion loan, most of it reserved for next year, on condition that the country continue to run a large primary surplus in the government budget. In this way the Fund maintains a strong arm over Brazil's next government, almost surely to be drawn from the Left. Any significant move toward fiscal expansion would trigger revocation of the promised loan, followed by capital market chaos. Or so one is led to suppose.

Right now, Brazil is in the grip of recession. With low demand for imports, the country has a trade surplus. It has, nevertheless, a substantial deficit on current account, most of which must be payment of interest due on external debts. This is offset by capital inflows, which are not, however, mainly new investments - currently low, owing to the depressed state of internal demand - but operating loans to existing business and the sale of existing national assets to foreigners. In short, Brazil's external balance today is a matter of mortgaging or selling property to pay interest, meanwhile hoping that things will somehow get better.

The IMF's requirement that Brazil maintain a primary budget surplus amounts to a prohibition against fighting recession by increasing domestic demand, an action would raise domestic investment, move the trade balance back into deficit (and the current account even more so), which in turn would require that foreign investors be found who are actually willing to bankroll new activity. Of course, such investors do not exist. If they did, the IMF would not be in the picture.

Conversely, the pressure to maintain a trade surplus is a device for balancing the existing willingness of foreigners to buy Brazilian assets against the existing burden of debt service. In part because of the political climate, that willingness is eroding more rapidly than Brazil can manage by shrinking real activity and curtailing imports. Panic therefore threatens from day to day. The short run purpose of the loan is merely to shift the timing of panic back in time so that it occurs under the new government instead of the old. A report in the New York Times on August 21, 2002 makes this clear:

American and European banks have all been scaling back their lending to Brazilian exporters and manufacturers in the last six months. Most are refusing to comment on their willingness to jump back into that market on the heels of the fund's big loan deal.

In the medium term, if the new government respects the conditions of the loan, the effect must be to finance a continuing reduction in private capital inflows, substituting debt to the IMF for exposure to private external investors while maintaining external debt payments to satisfy older creditors. It is probably not accidental that the net IMF loan for next year is roughly the same size as the present surplus on capital account.

Nothing here holds out any hope that Brazil's high indebtedness and interest obligations can be reduced. There is no amortization plan. Therefore, unless something does turn up (for instance, massive price increases for orange juice and coffee, which are not very likely), the outlook is for another IMF loan, and another, and another, into the indefinite future, until the private foreign sector is safely divested of its Brazilian holdings. 
There is also nothing in the loan that holds out the prospect for economic progress in Brazil itself. Neither increased public spending nor increased imports can be financed from it. Hence the loan represents no new money for the benefit of Brazilians, except to the extent that wealthy Brazilian nationals also transfer their assets abroad, and that locals purchase durable imports while they can. It is a standstill, not a progressive package, whose purpose is to keep the wheels of finance spinning, aimlessly, on the Brazilian beach.

Who benefits? In the first place, private holders of Brazilian assets, who have an opportunity to escape before a severe devaluation. In the second place, foreign bankers, whose loans will receive interest longer than would otherwise be the case. And in the third place, domestic political forces inside Brazil who oppose growth in public services and social reform.

What is not clear is why a Brazilian government of the Left, elected with a mandate to rule in the interest of the working population, should sacrifice its freedom of maneuver to these interests. It would be one thing if the loan held out a prospect of an early return to net new borrowing in support of state policy and private activity, but this is not the case. Instead, the loan is more properly thought of as a form of blackmail. The IMF promises, in effect, to help maintain an illusion of business as usual, during which interval the new government can occupy its offices in Brasilia and enjoy the perquisites of power, but only so long as no actual changes of policy are made. The threatened alternative, if the terms are broken, is financial chaos no doubt accompanied by concerted efforts to destabilize the new regime.

In particular, has Luiz Inacio Lula da Silva worked for so many decades to build the Workers' Party, only to govern on such diminished terms? Or is he prepared seriously to consider an alternative strategy? And if so, of what should it consist? And - while the hostility of the U.S. government is a foregone conclusion - what should be the attitude of the people of the United States to such an alternative approach?

\section{THE MYTH OF SOUND FINANCIAL POLICIES}

Brazil is a large, resource-rich, industrialized developing country with a history of interventionist policies in several industrial areas, including aerospace, computers and energy. It is the economic center of gravity in Latin America. The country's notorious flaw lies in income and wealth inequalities higher virtually than anywhere on earth, and a ruling elite very much aligned to the sectarian interests of the wealthy. A weak regulatory regime persists, particularly with respect to newly privatized sectors. Taxes have never been raised sufficiently to finance a satisfactory mass urbanization, and the country's vast national resources have not been protected or developed in sustainable fashion. Capital, moreover, has been free to take flight whenever policy threatened to move in these directions.

A case could once have been made for capital market openness in Brazil on the ground that the country was short of capital resources, and these could only be 
acquired abroad. But that case was valid for at most the extremely short period between 1973, when the old Bretton Woods institutions were dismantled, and 1982, when the resulting explosion of private debts culminated in economic collapse. During the oil shocks, Brazil did manage to finance growth and its import bill from abroad - but of course it could not do so on a sustainable basis. Ever since then, Brazil and the rest of Latin America have labored under the dead hand of past debts, unpayable except by selling off existing capital assets. There is no serious case that airlines, roads, power grids and telecommunications networks actually function better under foreign ownership. At present the entire case for privatization is financial: it raises resources to permit the continued servicing of past debts.

For what purpose? The rationalizing argument behind current IMF programs is that countries which follow "sound" financial policies — balanced budgets, tight money, deregulation and privatization of capital assets - will be rewarded by a stamp of creditworthiness. They should then benefit by being able to borrow from private capital markets on favorable terms, relative to their own histories and the record of countries who are less responsible. In principle this should mean that they can run deficits on their trade accounts, loan-financing the purchase of capital good imports to support development, and maintaining high levels of economic growth and job creation. They should be able to do all of this, and still attract inflows of direct foreign capital investment.

It has been clear for several decades, however, that this argument is a myth, that the promised land it envisions is a mirage. If it were not, what would Brazil be able to complain about? The country has a trade surplus and a primary surplus on the government budget. The source of deficits in both accounts relates to the payment of interest on past debts. To run a surplus on current account - reducing imports by another twenty billion dollars or so - would require massive further deflation of the real Brazilian economy. This would destroy the tax base and greatly worsen the public budget. Thus, there is no way to improve Brazil's accounts from their current position, short of an export boom - which depends on external demand over which Brazil has no control — or else a write-down of the past debt. But of course the very purpose of Wall Street's interest in Brazil is to get paid, as much as possible, for the past loans.

The Brazilian particulars illustrate a general point. The running of "sound policies" does not translate to favorable treatment on Wall Street. Instead, private investor judgements are driven largely by considerations over which national policies in developing countries have no influence at all. These include most notably conditions in other developing countries, and conditions in the United States.

Conditions in other developing countries periodically affect Brazil through contagion in financial markets. Upheaval and financial crisis in Russia, in 1998, directly affected the risk exposure of many "emerging markets" funds. Forced to account for the rising risk in Russia, they reacted by reducing exposure in other "risky" markets, such as Brazil, even though there was no connection between Brazilian and Russian economies at that time. Similarly, contagion from Argentina itself only recently a "model country" from the standpoint of the IMF — is affecting 
Brazil now. Brazil is being punished by the financial markets because of the failure of the IMF's sound-money prescriptions as they were applied in Argentina, even though Brazil did not follow the Argentine road of full acquiescence in the IMF's neoliberal schemes.

U.S. policies and internal conditions affect Brazil through their influence on relative rates of return facing investors. In the late 1990s, with a "flight to quality" compounded by the bubble mentality of the technology sectors, capital flowed into the United States and away from developing economies such as Brazil. Now that the bubble has collapsed, so has the appetite for emerging country risk, and perhaps also the capacity to purchase Brazilian assets. This too is beyond Brazilian control.

It follows that the best and perhaps the only route available to Brazilian policymakers acting on their own to restore growth and expand public goods and services in the short run must involve a reduction of debt payments. The easiest way to achieve this is, simply, to reduce payments, meanwhile imposing strict controls over capital flight and asking for a full renegotiation of financial terms. Alongside these measures, the Real would be devalued, and interest rates reduced to accommodate both exporters and import-substitution. This is the model followed by Russia in 1998, and the result was, in fact, a modest revival of domestic production after a terrible crash. Since that time, the crisis in Russia has eased, even though the vast damage done since the advent of shock therapy has not been overcome.

The case against a policy of debt reduction comes in two parts, one of which is specious, but the other must be taken more seriously. The specious argument holds that the capital market will punish Brazil for its defiance. The difficulty with this argument is straightforward: Brazil presently enjoys no benefit from its participation in world capital markets. Even the IMF package serves, from the standpoint of ordinary Brazilians, merely to keep up appearances. It is self-evident that to interrupt the recycling of IMF loans into debt service would change nothing in real terms, while the effective imposition of capital controls - if technically possible in Brazil's case - would slow the exit of private investors and so the decline of domestic asset prices. It does no harm, nor is it dishonorable, to acknowledge a bankruptcy that exists. The main effect is to put an end to the outflow of inside money trying to escape beforehand. Although affected investors obviously do not welcome this sudden loss of freedom, there is no moral or ethical basis on which they can claim a greater "right to escape" than that of ordinary workers and other citizens to whom the market grants no such opportunities.

The more serious objection is that Brazil's internal political stability may be threatened by a policy undertaken in the national interest. This is the danger of subversion from the outside. The interests of international finance protect themselves by the means at their disposition. There is a long history of this in Latin America, extending to present-day Venezuela, where the complicity of the U.S. State Department and no doubt other services in recent and continuing events is clear. In the Russian case, such risks are much smaller, because the government rests on the bedrock of its security services, whose defects are well-known but whose national 
loyalties do not seem to be in question. How well a new Brazilian government may be able to meet this danger is a matter of internal politics on which a distant observer cannot speak with any authority. But it is there - in the "crisis of confidence" - and not in the supposed power of a market, that the true danger lies.

\section{IS THERE A BETTER WAY?}

Is there a better way, for Brazil and the world, than a complete rupture between North and South on financial matters? And are the national interests of the United States absolutely congruent with those of our leading financiers, so that policy with respect to international development can be safely left to their judgment and in their hands? Or is it possible that, to borrow a phrase, another world is possible after all?

Surely it has to be. The liberal economic vision, with multilateral clearing, relatively free and open trade, easy flow of technology, travel, migration and human learning, has a core of virtues. It has helped to create a far more open and attractive world, in many important respects, than could ever have been achieved under the previous regimes of colonialism and empire. The world is today safer from global war than it was in the first half of the last century. Trade and peace do go hand in hand - most of the time. There are reasons why the enduring success of such a system remains an ideal for many intelligent and well-meaning people.

But at the same time, the world we inhabit fails to rise to the standard set by the liberal ideal. Particularly over the past two decades, the postwar trading framework has become hopelessly distorted by the hegemony of the U.S. dollar, by unsustainably high interest rates, by debt deflation and by capital flight. The asymmetries of a world so structured are intolerable, as they lead to unprecedented prosperity in the rich countries and deepening crisis for the poor. It is a minor miracle that they have not long since led to a full-scale insurrection against U.S. global leadership. But the fact is, such an insurrection may not be very far off. There already exists very widespread rejection of American world leadership by the populations of developing countries world-wide, and the reputation the United States once enjoyed as a pillar of multilateral order, respect for differences and fair play has long since been squandered. This cannot fail to translate into political terms sooner or later.

The British economist John Maynard Keynes had already recognized this issue with his characteristic clarity in the design of the Bretton Woods institutions - the World Bank and the IMF - in 1944. Keynes, as the third volume of Robert Skidelsky's biography makes especially clear, was an economic and a political liberal. He favored free markets and liberal trading arrangements insofar as they could be made to work. But he also had not forgotten the fact, which the Depression had driven home to all observers, that free markets are inherently unstable and prone to collapse.

Keynes understood that the characteristic structure of unregulated internatio- 
nal finance placed the bankers and the creditors in the dominant position, and so worked to force adjustment on the debtors. This was locally rational in financial transactions but disastrous for the system as a whole. Individual debtors would be forced to contract their economies in order to meet their interest payments. Their demand for imports would diminish, and so would the exports of their suppliers. In the end, the entire economic system would contract, and no one would be further forward in the ability to pay their debts.

The purpose of the Bretton Woods institutions, in Keynes's plan, was to evade this trap. The substantial mechanism was to be a multilateral clearing union, with authority to issue overdrafts to debtors - in effect to print international money. Under Keynes's scheme, it would be creditors who would have to adjust, by expanding their domestic economies, their employment and their absorption of imports until their consumption of imports rose to match their sale of exports. Otherwise, the creditors would face legitimate discrimination against their exports. In this way, the system would balance at high levels of employment (and the principal economic risk, of course, would be international inflation rather than global slump). No member country would, in Keynes's vision, be required to contract domestic economic activity and forego full employment simply in order to meet international clearing obligations or pay debt service to foreigners.

Keynes did not get his way in the negotiations. The American side, led by Harry Dexter White, insisted on a system dominated by lender interests. And as a result the Bretton Woods institutions contributed almost nothing to postwar reconstruction until calamity threatened in 1948 and the Marshall Plan was put in place to avert it. After that, development largely proceeded under the impetus of cold and hot wars; that in Korea which jump-started the recovery of Japan, and that in Vietnam which provided similar service for Korea and much of Southern Asia.

The IMF began developing its modern regimens of debtor adjustment - devaluation plus deflation - for imposition in Europe in the late 1960s. There followed a brief moment, in the aftermath of the oil shock of 1973, when the Fund might have emerged as the principal conduit for the "recycling of petrodollars" to the oil-importing countries of the developing world. But the Nixon administration blocked this. Instead, the job of financing development was turned back to the major commercial banks, along with their European and Japanese colleagues. They made the necessary loans on commercial terms and at variable interest rates keyed to the London Interbank Offer Rate (LIBOR). Development from that point forward was to proceed on commercial terms and "free market" principles, at interest rates determined after the fact by the monetary authorities of the United States.

These arrangements were doomed from the beginning. They collapsed even sooner than they might have otherwise, when Paul A. Volcker and the Federal Reserve pushed American interest rates past twenty percent in their 1981 campaign against inflation. The result was a global crisis of debt, insolvency and perpetual debtor adjustment that afflicts the entire developing world (except for India, China and a handful of South Asian city-states) to this day.

The original authors of the IMF and Bank generally supposed that the United 
States would remain in its immediate post-war position of a strong surplus country and creditor to the rest of the world. Thus dollars could be "scarce" and, if they were, international liquidity would have to be issued in some other medium. This rather soon proved to be a colossal misjudgment; instead the U.S, went into deficit and eventually the United States became the world's largest debtor. The world became so awash in dollars that the proposed international unit of account, originally the bancor and in its etiolated modern form the "Special Drawing Right" faded into insignificance. Today, the dollar is the world's reserve currency, and the international position of the United States depends on this.

So long as the world is willing to take and hold United States assets, including liquid dollars, this system works - and shamefully to the interest of Americans. The resulting high value of the dollar means that we consume comfortably, and in exchange for very little effort, the products of hard labor by poor people. We live on the interest skimmed from the meager living available to factory workers in São Paulo; in exchange for providing otherwise unavailable liquidity to the world system. (Our situation is akin to that of say Australia when gold fields were discovered there in the late $19^{\text {th }}$ century, except that, in our case, no actual effort is required to extract the gold.) And meanwhile, we are not obliged to invest unduly in maintaining our own industrial base, which has substantially eroded since the 1970s. We can afford to splurge on new technologies and telecommunications systems whose benefits were, to a very great extent, figments of the imagination. And even when the bubble burst in those sectors, life went on, for most Americans, substantially undisturbed - at least for now.

But for how long will the system of dollar hegemony endure? There can be no definitive answer; the few economists who have worried about this issue are very far from agreement. On one side, it is argued that the dominant currency holds a "lock-in advantage"; there are economies associated with keeping all reserves in one basket. The United States, in particular, is in a strong position to oblige foreign central banks to absorb the dollars that private parties may not wish to hold, at least within elastic limits. Control of oil by U.S. allies and satellites will require other importers to buy dollars in order to buy oil, though it is not obvious that it requires anyone to hold those dollars very long, except as a hedge against price increases or homecurrency devaluations.

Against this, the question remains: will foreigners be willing to add to their holdings of U.S. assets at the rate consistent with the U.S. current account deficit at full employment? The amount to be absorbed is in the range of a half trillion dollars per year. This was easily handled while asset prices were rising. But now that they are falling, dollar assets are not so safe as they once were. If foreigners are not willing to absorb at the requisite rate, and if asset prices do not quickly fall to the point where stocks appear cheap, then dollar dumping is, sooner or later, inevitable. Otherwise, the United States must slow the rate which liquidity is issued, by restricting its imports, which it can only do by holding down economic growth and keeping incomes well below the full employment level. In that situation which may already have arrived — the United States joins Brazil and other develo- 
ping nations as a country effectively constrained by its debts. Indeed the world prognosis from that point forward becomes grim, since high levels of American demand have been just about the only motor of growth and development (outside, perhaps of China and India) in recent years.

\section{THE UNITED STATES AS A DEBTOR NATION}

There are economists who advocate dollar devaluation, believing that the richer countries of the world would quickly rally to purchase increasing quantities of madein-America exports, thus reversing the manufacturing decline of the past twenty years. But this is very unlikely. Exports to the rich regions may not be very price-sensitive.

And exports to the developing regions are very sensitive to income and credit conditions, which would get worse. At least in the short and medium term, there is no foolproof adjustment process to be had by these means. Where a high dollar gives the United States cheap imports and capital inflow to finance domestic activity, a falling dollar would have opposite effects. A falling dollar would raise the prices of U.S. imports, especially from the richer countries. Meanwhile, a declining dollar would hit at the value of the reserves of the developing countries, and so work, on that account, to diminish their demand for our exports. The most likely outcome from a dollar devaluation is therefore a general deepening of the world slump, combined with pressure on American financial institutions as global investors seek safer havens in Europe.

This "elasticity pessimism" (very much shared by Keynes in his day) and the specter of financial vulnerability means that for the United States the combination of falling internal demand, falling asset prices, and a falling dollar represents a threat that can best be described as millennial — an empire-shaking, regime-changing combination of events. (My colleague Randall Wray has called it the "perfect fiscal storm"). The consequences at home would include deepening unemployment. There would little recovery of privately financed investment, amid a continued unraveling of plans - both corporate and personal - that had been based on the delirious stock market valuations of the late 1990s. The center of the world banking industry would gradually move, presumably to continental Europe. Over time, the United States could lose both its position as the principal world beneficiary of the financial order, and its margin of maneuver on the domestic scene. This would be not unlike what happened to the United Kingdom from 1914 to 1950.

It is not obvious that senior financial policymakers in the United States have yet grasped this threat, or that there is any serious planning underway to cope with it - apart from a simpleminded view among certain strategic thinkers about the financial advantages of the control of oil. Instead it appears that the responsible officials are confining themselves to a very narrow range of debt management proposals, whose premises minimize the gravity of the issue and whose purpose is to keep the existing bonds of debt peonage in place as long as possible. 
A new paper by the Derivatives Study Center, a Washington study group, outlines three major proposals for dealing with the problems of sovereign debt. One of these was authored by chief economist Anne Krueger at the IMF, another is associated with Treasury Undersecretary John B. Taylor, and a third is due to a group of private economists associated with the global debt relief campaign, and headed by Kunibert Raffer.

The IMF and Taylor proposals provide alternative ways of addressing a very narrow issue in debt negotiations, namely the incentive for renegade creditors to resist a write-down of their own assets and so to hold out for full payment. This is a classic free-rider issue, since the possibility of paying off any one creditor at face value rises as other creditors accept to be paid smaller amounts. The Fund would deal with this problem through a new formal restructuring mechanism that would bind all creditors to terms acceptable to a majority; the Taylor proposal would accomplish much the same thing (though in a very much more distant future) by providing that new debt contracts carry a collective action clause permitting the will of the majority of creditors to bind the entire group.

Neither the IMF nor the Taylor proposals address the systemic problem of excess and unpayable debt. Their thrust is merely to prolong the present pre-bankruptcy stage of financial relations for as long as possible - shaving and stretching out debt repayments so as to match the ability to pay to the willingness of foreign capital to acquire developing country assets through liberalization and privatization. In this way, they implicitly assume what has already proven to be impossible, namely that the private capital markets will eventually produce "development" to which poor countries aspire. Nothing in either protocol would protect the populations or the public programs of any developing country.

The Raffer proposal makes an effort along these lines, by proposing the creation of an international adjustment mechanism akin to the municipal bankruptcy proceedings available under Chapter Nine of the U.S. bankruptcy code. This proposal for "restructuring with a human face" would give citizens of debtor countries a legal right to be heard in debt negotiations, and so would permit countries to protect some of their social services and core infrastructure investments from disruption in the restructuring process. This proposal has an undoubted claim to enlightened sympathy, and would very materially ease the burdens of adjustment on poor countries in debt restructurings. But no more than the other proposals does it address the larger problem facing the world economy today, namely the breakdown of a functional finance in support of the development process.

But if the United States runs a risk, within (say) a decade or two, of joining those countries for whom the discipline of the international monetary order means continuous debtor-adjustment, as a result of a widespread diversification away from the dollar as a reserve asset, then a new element will enter the picture. It will become part of the national interest of the United States - if not necessarily that of its financial industry - to collaborate in the reconstruction of a global order that serves the interests of debtors at least as well as creditors. It will become the American interest to switch sides in the debt wars, and to join forces with the de- 
veloping countries whose interests lie in rebuilding a multilateral international monetary structure, and so provide a safe path to the orderly liquidation of the dollar overhang, and the restoration of autonomy to growth-oriented national development policies.

What would this mean in practice? In broad terms, it would mean that the negotiations antecedent to Bretton Woods, so admirably recounted by Skidelsky, would have to be recreated. But this time, the United States would have to take the role that Britain, anxious to protect its national autonomy in difficult financial conditions, took in 1944. (In that environment, Britain spoke for all the habitually indebted nations of the world, in favor of a global order that would force creditors to bear the burden of adjustment.) Whereas the role played by the United States would be taken on by the world's emerging creditor power, the European Union.

There is every good reason to think that the outcome of such a revisited negotiation would be more favorable to the world's beleaguered debtors than was the case in 1944. The United States remains today a dominant diplomatic and military force, which the European Union is not. And the U.S. economy is far more globalized, with more natural links of trade and investment, to the developing countries, than are the Europeans. Should the U.S. one day switch sides in the global financial struggles, remarkable things might happen in a fairly short time.

Such a change is difficult to imagine today. The political processes of the United States would first have to be thoroughly overhauled - the money-changers would have once again to flee their positions in the temple. But circumstances have a way of dictating political position, sooner or later. It has only been a bit more than a century since the U.S. did in fact stand as the world's premier representative of debtor nations. It was only some seventy years ago that Franklin Roosevelt inaugurated the Good Neighbor Policy, acknowledging the sovereign right of Latin American countries to escape from the burden of unpayable debts. It may not take that long before we come full circle once again, if motivated by practical necessity in the pursuit of full employment. Perhaps the oncoming clash between Brazil's people and the global financial order will help motivate ordinary Americans to rethink on which side we should stand now. 